\title{
Cattle Trampling of Simulated Ground Nests under Short Duration and Continuous Grazing
}

\author{
B.H. KOERTH, W.M. WEBB, F.C. BRYANT, AND F.S. GUTHERY
}

\begin{abstract}
Trampling by cattle on simulated ground nests were compared between continuous (CONT) grazing at $8.0 \mathrm{ha} / \mathrm{steer}$ and short duration grazing (SDG) at $5.3 \mathrm{ha} / \mathrm{steer}$. Trampling losses were similar under CONT grazing (15\%) and SDG $(9 \%)$ at a nest density of $1 /$ ha. Percentage trampling loss did not increase at higher nest densities under either grazing regime. Nest survival curves indicated a loss rate of $2.21 \% / w k$ under CONT grazing and $2.09 \% / w k$ under SDG. The data from this study suggest there is no reason for concern that SDG with cattle will increase trampling loss of ground nests over CONT grazing.
\end{abstract}

Knowledge of factors affecting the nesting success of birds is essential for proper management. Because many North American species nest on the ground, a potential source of egg loss is trampling by domestic livestock. Reported trampling loss rates for ring-necked pheasants (Phasianus colchicus) and gray partridges (Perdix perdix) have been less than 5\% in various areas (Eklund 1942, Knott et al. 1943, McCabe and Hawkins 1946). In Ohio, Dambach (1944) found more cavity-nesting birds in grazed than in ungrazed woodlots and implied that cavity nesters would be more successful than ground nesters when woodlots are grazed. Buttery and Shields (1975) ranked summer grazing as having the highest potential impact on birds because it occurs during the nesting season. They speculated that the benefits of deferred- or restrotation grazing could be offset by heavy use in other pastures that not only reduced food and cover but also increased the trampling of ground nests.

In Texas, the emergence of specialized grazing systems has complicated the relation between grazing and trampling losses. These systems concentrate livestock in relatively small areas for short periods of time. This high stocking density is rotated rapidly over the range until the total area has been grazed and then the cycle is repeated. Such a regime is called short duration grazing (SDG) when the grazing period is 7 days or less (Bryant et al. 1982).

Westmoreland et al. (1981) and Bryant et al. (1982) expressed concern that high stocking densities of livestock under SDG could increase nest losses due to trampling. But when Bryant et al. (1982) modeled the relative danger to ground nests of cattle grazing under various grazing regimes, they suggested that higher grazing losses under SDG than continuous (CONT) grazing were unlikely. Because this has not been tested, this study was designed to evaluate losses of simulated ground nests due to grazing by cattle under CONT grazing and SDG.

\section{Study Area and Methods}

The study area was on the Texas Tech University Campus, Lubbock County, on the Southern High Plains. The study pastures

At the time of this research, Koerth and Webb were research associates and Bryant and Guthery were assistant and associate professors, Department of Range and Wildlife Management, Texas Tech University, Lubbock 77409 . Koerth's present address is Texas Agric. Exper. Sta., Rt. 2 Box 589, Corpus Christi, TX 784 10. The Noxious Brush and Weed Control Program, Texas Tech University, and the USDA Forest Service, Rocky Mountain Forest and Range Experiment Station, Great Plains Wildlife Research Laboratory, supported this work. This is Technical Article T-9-276, College of Agricultural Sciences, Texas Tech University.

Manuscript received November 19, 1981. were on 32 ha (CONT) and 48 ha (SDG) of native rangeland dominated by mesquite (Prosopis glandulosa) overstory with an understory of buffalograss (Buchloe dactyloides), blue grama (Bouteloua gracilis), and broomweed (Xanthocephalum spp.). The CONT pasture was stocked at $8.0 \mathrm{ha} / \mathrm{steer}$. The SDG treatment was divided into $16,2.75$-ha paddocks and stocked at an overall rate of $5.3 \mathrm{ha} / \mathrm{steer}$. When steers were in a paddock, the stocking density was $0.83 \mathrm{ha} / \mathrm{steer}$. Under SDG, the single herd of steers grazed each paddock 3 days and was rotated through all paddocks on a 48-day cycle.

In May 1981, simulated nests were placed on CONT and SDG pastures to achieve 3 densities: 1,2 , and 3 nests/ha. Clay pigeon targets $(1 /$ nest) were used as simulated nests to avoid confusion between a nest lost from predation and one lost because it was trampled and also to remove predation as a source of variation. We tried using chicken eggs as dummy nests but terminated this approach because after 1 week, predation losses exceeded $90 \%$ and data on trampling losses were not forthcoming.

Pastures in both treatments were divided into l-ha grids to achieve systematic distribution of nests. An effort to simulate nest habitat selection by birds was impractical for this study. Each grid subsequently was divided into 4, 0.25-ha quadrants. A simulated nest was placed under natural vegetation in quadrant $I$ at the initiation of the study. At 2-week intervals, 1 simulated nest was placed in a quadrant until 3 of the 4 quadrants contained a simulated nest. Simulated nests were examined weekly for 7 weeks, a time span that would include the laying and incubation period for most birds (Edminster 1954). Consequently, data from each quadrant served as a replication at a nest density of $1 /$ ha. Nest densities of $2 /$ ha and $3 /$ ha were not replicated but were achieved by combining data from quadrants I and II and I, II, and III, respectively. These nest densities were selected because they were consistent with previously reported data. Duebbert (1969) found a nest density of $1.25 /$ ha for waterfowl in South Dakota and Leopold (1933) reported 2.5 nests/ha for bobwhites (Colinus virginianus).

Differences in trampling rates between grazing treatments were tested using analysis of variance. Linear regression of nest survival on time was used to estimate the rate of nest loss/week.

\section{Results and Discussion}

At simulated nest densities of $1 /$ ha, the average trampling loss was similar $(P>0.05)$ under CONT grazing (15\%) and SDG (9\%) (Table 1). Although one expects grazing losses to increase when livestock are concentrated in a short-duration system, several factors work against these losses. First, cattle may travel more under CONT than under high-intensity-low-frequency grazing (Anderson and Kothmann 1980), which is similar to SDG except fewer paddocks are used and there usually are longer periods of grazing per paddock. Second, cattle apparently travel less in smaller pastures than in larger pastures (Herbel and Nelson 1966, Durham 1975, Malechek and Smith 1976). The probable decreased travel under SDG compared to CONT grazing decreased the likelihood of trampling loss. Third, at any point in time, $100 \%$ of the CONT 


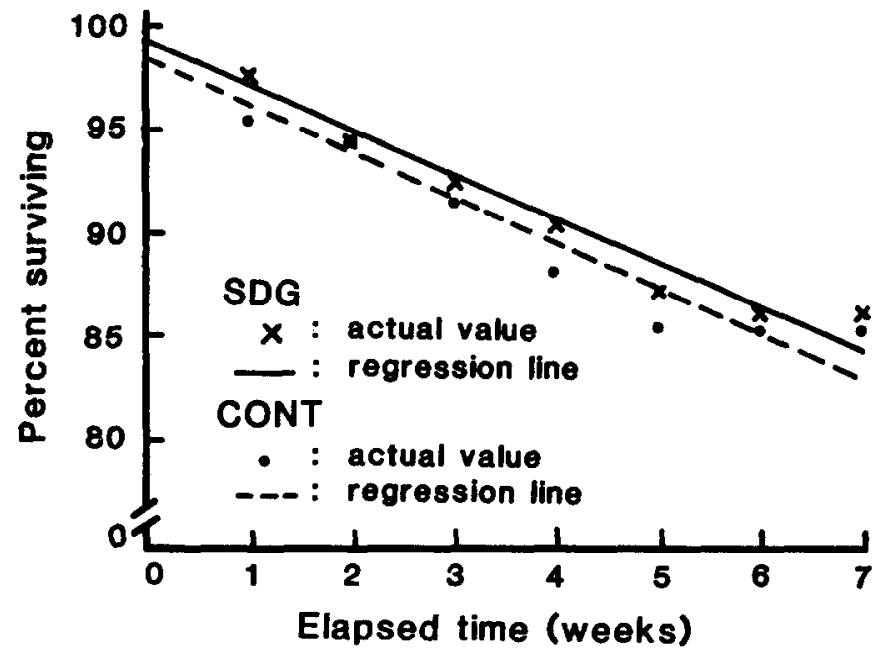

Fig. 1. Survival curves for simulated ground nests under short-duration grazing (SDG) and continuous grazing (CONT).

treatment was subject to trampling whereas only $6 \%$ of the SDG treatment was subject to trampling. We note also that during a 40-day laying and incubation period, which is typical for North American galliformes (Edminster 1954), only 87\% of the SDG treatment was grazed whereas $100 \%$ of the CONT treatment was grazed.

Percentage trampling loss of simulated ground nests did not appear to increase with increased nest densities under either CONT grazing of SDG (Table 1). Al densities of 2 and 3 nests/ha, trampling losses were slightly higher under CONT grazing than under SDG, but the differences could not be tested statistically.

Nest survival curves over a 7-week period were similar under the two grazing regimes (Fig. 1). Slopes of the curves indicated a nest loss rate of $2.21 \%$ / week and $2.09 \%$ / week under CONT grazing and $S D G$, respectively.

Almost half $(47 \%)$ of the simulated nests trampled by cattle under CONT grazing were on $31 \%$ of the pasture closest to water. This agrees with Buttery and Shields' (1975) observation that livestock concentrations near water could result in high trampling loss.

\section{Conclusions}

Trampling loss is only one of many factors involved in the grazing-ground nest interaction. Grazing may predispose nests to predation (Errington 1933), or, on the other hand, create spatial heterogeneity in herbaceous cover that increases search time by predators and reduces the number of nests they find (Bowman and Harris 1980). If grazing is heavy enough, vegetation characteristics may be altered such that habitat-selection mechanisms for nesting are not triggered for some species (Buttery and Shields 1975).

Also, trampling losses per se are an incomplete criterion by which to judge the effects of grazing regimes on bird production. Rotational grazing systems and longer pasture deferment have significantly decreased predation on artificial nests compared to continuous grazing (Baker 1979). Merrill (1975) reported a higher density of Rio Grande turkey (Meleagris gallopavo intermedia) nests under deferred-rotation than under continuous, yearlong grazing. Because rotational grazing systems often increase herbaceous cover and forage production (Merrill 1975), the higher densities could have been more a function of better nesting habitat than of grazing system impacts on trampling losses, especially since turkeys on the Edwards Plateau of Texas prefer to nest where cover is at least $46 \mathrm{~cm}$ tall (Cook 1972). Bryant et al. (1982) concluded that continuous grazing rarely would be preferred over a grazing system in management of gamebird habitat, but they noted a deficiency in knowledge on the response of wildlife to SDG.

In spite of the complexity of the relation between grazing and trampling losses of ground nests, conclusions can be drawn from
Table 1. Trampling losses (\%) of simulated ground nests under continuous and short duration grazing on the study site in Lubbock County, Texas.

\begin{tabular}{lcccccc}
\hline & \multicolumn{2}{c}{ Continous grazing } & & \multicolumn{2}{c}{ Short duration grazing } \\
\cline { 2 - 3 } \cline { 6 - 7 } Nest density & $\mathrm{N}$ & $\%$ loss & & $\mathrm{N}$ & \% loss \\
\hline l/ha & 961 & 15 & & 1442 & 9 \\
$2 /$ ha & 61 & 11 & & 93 & 10 \\
$3 /$ ha & 93 & 13 & & 141 & 9 \\
\hline
\end{tabular}

13 replications@32 nests/replication.

23 replications@ 48 nests/replication.

the present study. First, there appears to be no reason for concern that trampling losses by cattle will be higher under the SDG regime used in this study than under CONT grazing, even though stocking rates were higher under SDG. By inference, trampling losses should be lower under SDG than under CONT grazing at similar stocking rates. Lastly, the only alternative to reduce trampling losses under CONT grazing is to lower the stocking rate. Under SDG, however, increasing the number of pastures while holding the stocking rate and days of grazing per pasture constant should decrease trampling losses. This would occur because a smaller percentage of the area would be grazed during any laying and incubation period.

\section{Literature Cited}

Anderson, D.M., and M.M. Kothmann. 1980. Relationship of distance traveled with diet and weather for Hereford heifers. J. Range Manage. 33:217-220.

Baker, B.W. 1979. Habitat use, productivity, and nest predation of Rio Grande turkey. Ph.D. Diss. Tex. A\&M Univ., College Station. 43 p.

Bowman, G.B., and L.D. Harris. 1980. Effect of spatial heterogeneity on ground-nest depredation. J. Wildl. Manage. 44:806-813.

Bryant, F.C., F.S. Guthery, and W.M. Webb. 1982. Grazing management in Texas and its impact on selected wildlife. P. 94-112.In: J.M. Peek and P.O. Dalke, eds. Wildlife-livestock relationships symposium: Proceedings 10. Univ., Idaho, Forest. Wildl, and Range Exp. Sta., Moscow.

Buttery, R.F., and P.N. Shields. 1975. Range management practices and bird habitat values. P. 183-189. In: Proc. symp. on the manage. of forest and range habitats for nongame birds. USDA Forest Serv. Gen. Tech. Rep. WO-1.

Cook, R.L. 1972. A study of nesting turkeys in the Edwards Plateau of Texas. Proc. Southeastern Assoc. Game \& Fish Comm. 26:226-244.

Dambach, C.A. 1944. A ten-year ecological study of adjoining grazed and ungrazed woodlands of northeastern Ohio. Ecol. Monogr. 14:225-228.

Duebbert, H.F. 1969. High nest density and hatching success of ducks on South Dakota CAP land. Trans. N. Amer. Wildl. Conf. 43:218-228.

Durham, A.J. Jr. 1975. The botanical and nutritive composition of winter diets of cattle grazing native prairie on the Texas Gulf Coast. M.S. Thesis. Texas A\&M Univ., College Station.

Edminster, F.C. 1954. American game birds of field and forest. Charles Scribner's Sons, New York.

Eklund, C.R. 1942. Ecological and mortality factors affecting the nesting of Chinese pheasant in the Williamette Valley, Oregon. J. Wildl. Manage. 6:225-230.

Errington, P.L. 1933. The nesting and the life equation of the Wisconsin bobwhite. Wilson Bull. 45:122-132.

Herbel, C.H., and A.B. Nelson. 1966. Activities of Hereford and Santa Gertrudis cattle on a southern New Mexico range. J. Range Manage. 19:173-176.

Knott, N.P., C.C. Bell, and C.F. Yucom. 1943. Nesting of the Hungarian partridge and ring-necked pheasant in Whitman County, Washington. J. Wildl. Manage. 7:283-291.

Leopold, A. 1933. Game management. Charles Schribner's Sons, New York. $481 \mathrm{p}$.

Malechek, J.C., and B.M. Smith. 1976. Behavior of range cows in response to winter weather. J. Range Manage. 29:9-12.

McCabe, R.A., and A.S. Hawkins. 1946. The Hungarian partridge in Wisconsin. Amer. Midl. Natur. 36:1-75.

Merrill, L.B. 1975. Effect of grazing management practices on wild turkey habitat. P. 108-112. In: L.K. Halls, ed. Proc. Third Nat. Wild Turkey Symp. Texas Chapter-The Wildl. Soc., Austin.

Westmoreland, G., H. Dietz, R. Johnson, H. Senne, J. Norris, F. Sprague, J. Henson, and G. Valentine. 1981. Evaluation of cell grazing systems. USDA Soil Conserv. Serv. Tech. Note, Range TX-1. Temple, Tex. 